\title{
Solutions to Strengthen the Internal Control System in Paper Manufacturing Enterprises
}

\author{
Thanh Thi Nguyen ${ }^{1}$, Dr. Ngoc Thi Bui ${ }^{2}$ \\ ${ }^{1}$ Accounting Department, Faculty of Economics and Business Administration, University of Hong Duc, Vietnam \\ ${ }^{2}$ Accounting Department, University of Labor and Social Affairs, Vietnam \\ Room No. 44, A8, 120 Hoang Quoc Viet Street, Cau Giay District, Hanoi, Vietnam \\ E-mail: buithingoc.ldxh@gmail.com
}

\begin{abstract}
In 2013, the Committee of Sponsoring Organizations of the Treadway Commission (COSO) provided a fairly comprehensive definition of internal control: "Internal control is a process affected by entity's board of directors, management, and other personnel, it is designed to provide reasonable assurance regarding the achievement of objectives relating to operations, reporting, and compliance". This definition indicates that internal control is indispensable to provide a reasonable guarantee for an organization's ability to achieve its goals and sustainable development. Currently, the internal control system in Vietnamese paper manufacturers has not met essential needs of the society. There are more than 500 paper manufacturing enterprises in the country, in which more than $90 \%$ are small enterprises, and in which internal controls are not effectively implemented. This paper examines reality of internal control in paper manufacturing enterprises in Northern Vietnam. Based on that, evaluation and measures are provided in order to improve internal control. Research results showed that there are five factors which directly affect internal control: control environment, risk assessment, control activities, information and communication, monitoring activities.
\end{abstract}

Keywords: Internal control, effectiveness of internal control, paper manufacturing enterprises.

\section{Introduction}

It is a challenge for corporate executives to design and operate the internal control system with management policies which is scientifically designed, and operated in a consistent and efficient manner, and system factors which are considered as a shield to protect business value. Developing internal control (IC) is, therefore, one of critical issues regarding the sustainable development of enterprises.

There have been many authors in Vietnam and abroad studying about internal control. In the world, some studies focused on internal control in terms of its influences on the effectiveness of organization's performance, helping the organization to achieve its goals: for example Cheng at al. (2015); Mongkolsamai at al. (2012); Morelo (2011); Muraleetharan (2011); Dinapoli (2007). Otherresearch considered internal control as a function of reducing risks such as studies of Arens \& Loebbecke (2006), Bičiulaitis (2001); Pfister (2009); Chorafas (2001); Giriunas (2012). In Vietnam, there were many authors studying about internal control such as Quynh \& Tue (2012); Tan (2016); Giang \& Le (2014). These studies showed that internal control is a basic function; provided a general analysis about internal control.

Research in Vietnam and abroad on IC is analyzed from different perspectives with various methods. However, when applied to each sector or each area, there exist different characteristics. Currently, paper manufactures in Northern Vietnam are mainly small and medium-sized enterprises, where establishment and implementation of IC have not been effective. Therefore, this study was conducted to evaluate the current situation and propose solutions to improve IC in paper manufacturing firms in Northern Vietnam.

\subsection{Theoretical Framework}

In an organization, internal control which is designed and operated in an appropriate and effective way will help to control risk, improve business efficiency and competitiveness, develop strategic direction towards sustainable development. 
Definition of inernal control: There are many perspectives on internal control, which can be divided in to two main perspectives:

Perspective 1: Internal control has influences on performance effectiveness of an enterprise, helps the enterprise achieve its objectives

In a report of Federal Reserve Bulletin in 1929, the first definition of IC was provided. According to the report, internal control is defined as a tool to protect money and other assets, as well as enhance performance effectiveness. The American Institute of Certified Public Accountants (AICPA) (1936) supposed that purposes of IC are not only protecting money and assets of others but also ensure accounting information of an organization. In addition, AICPA provided that all methods and measures are combined and applied in that organization in order to ensure the safety of properties, verify accuracy and reliability of information provided by accountants, enhance performance effectiveness and encourage compliance of established management policies. COSO (1992) showed 4 fundamental points of IC: IC is a process, IC is affected by human, IC provides a reasonable assurance, IC helps to achieve objectives. Dinapoli (2007) emphasized the role of each individual in an organization, from employees, managers to executives; each member plays a critical role in achievement of the organization's objectives. Moller (2009) focused on specific objectives of enterprises, and his definition mentioned "integrity and ethical values" which is a new, different perspective from previous ones.

Perspective 2: Internal control is a method of reducing risks

Pfister (2009) stated that during the process of analyzing data of enterprises, there exist certain risks which can affect the business results. The internal control system which is established and operated effectively can help enterprises identify and analyze risks, reduce and minimize them at an acceptable level. Chorafas (2001) supposed that the aims of IC are ensuring reliability of financial statements, identifying implicit or explicit risks existing in the enterprises, evaluating them and finding solutions. Bičiulaitis (2001) provided that in an environment when activities occur, IC must evaluate the impact of the elements around it; protect information because implicit risks may affect the enterprise's information.

From different perspectives on IC, essence of IC can be summarized as follows: Internal control is a process that is implemented consistently in an organization, from the board of directors, executives to all of its employees, adopting a series of activities, measures, plans, perspectives, regulations, policies, and efforts of those members to control all activities in the organization. Based on that, it also recognizes, prevents and addresses possible risks that may occur to ensure that the organization operates in a consistent and continuous manner with its established strategic direction towards sustainable development.

\subsection{Why Is It Necessary to Improve Internal Control?}

In the highly competitive business environment, apart from capital and technological issues, enterprises need to have a suitable internal control system to meet the market demands. When businesses implement IC effectively, it will help them achieve the following objectives: protecting enterprises' assets, ensuring the reliability of information, ensuring the implementation of legal regulations, as well as ensuring effectiveness of the operation. Especially in the fast-growing economic environment like Vietnam, most enterprises try to implement strategic business plans, invest in resources to develop and manage processes of IC. As a result, when enterprises participate in such a continuously developing environment, the risks that businesses face will not stop changing. Effective IC is an indispensable tool in corporate governance, helping the board of directors achieve business goals and prevent risks from happening to the organization.

\subsection{Constituent Elements of Internal Control}

There are various perspectives on constituent elements of the internal control system: according to Arens and Loebbecke (2006), constituent elements of the internal control system are: control environment, accounting system and monitoring activities. According to new auditing standard SAS 55, the internal control system includes: control environment, accounting information system and monitoring procedures. According to Quynh \& Tue (2012), the internal control system consists of four elements: control environment, information system, internal monitoring and auditing procedures. However, COSO (2013) supposed that internal control consists of five basic factors: control environment, 
risk assessment, control activities, information and communication, monitoring activities. The author assumed that the internal control system consisting of five elements will reflect an adequate and complete role of the internal control system in achieving objectives of an organization.

\section{Methodology}

\section{Characteristics of Sample}

The author focused on the enterprises with the total capital of more than 100 billion VND and the average number of employees over 200 people. The reason for selecting this sample is because most enterprises have IC but only large-scale enterprises have a complete internal control system. The fact is that raw materials are mainly concentrated in the North while the production capacity is concentrated mainly in the South. Therefore, the North has many advantages for the development of manufacturing paper products. The studying of paper manufacturers in the North which aimed at analyzing current situation, proposing a number of solutions to improve IC in the paper manufacturing enterprises in Northern Vietnam is completely appropriate. Annually, paper manufacturing business in the North also creates various jobs for thousands of workers and directly contributes to the state budget. (See appendix 2)

\section{Methodology}

This paper used a combination of research methods in order to collect data for the research process. Specifically:

- Primary data: Author collected primary data through survey, observation, interviews. The questionnaire includes with specific contents such as general information of the enterprise, control environment, risk assessment process, information and communication system, control policies and procedures, monitoring activities. The study was conducted during a period of 3 months (from September, 2017 to December, 2017). The respondents of questionnaires included: Accountants, members of supervisory board, departmental staff, the board of directors.

Questions in the survey were designed based on theories and specific characteristics of the enterprise. The questionnaire consists of two types of questions:

+ Open-ended questions: collecting specific information and characteristics of enterprises such as quality standards of quality, waste management standards.

+ Closed-ended questions: Providing options for the interviewer. Each interview lasted from 30 to 45 minutes with different respondents: from the board of directors, supervisory board, staff (Questionnaire is showed in Appendix 3).

After collecting data through survey and in-depth interviews, the authors synthesized, analyzed to clean the data, eliminated invalid answers. Then the valid data was analyzed on excel. (The table of results and questionnaire are showed in Appendix 3).

- Secondary data: Information was gathered through the collection of materials such as textbooks, lectures, research, statistical data from the General Statistics Office, data of the General Department of Taxation, website of the enterprise. The secondary data was analyzed to give conclusions.

The number of enterprises selected by the author to send questionnaires is 34 enterprises, each enterprise is sent one questionnaire. These companies have their main business activities in manufacturing paper. Among 34 questionnaires sent to enterprises, the author has collected 30 answers (response rate is 88.2\%). (List of Enterprises is showed in Appendix 1).

\section{Current State of Research}

In the industrial structure of the country, pulp and paper industry is classified as a heavy industry. In order to invest in projects of manufacturing pulp and paper, a huge investment is needed because companies must invest in not only facilities, machinery, but also construction of areas supplying raw material for the paper manufacturing project. The mere costs of building facilities, production lines are already high. To invest in a project of manufacturing paper, an enterprise has to spend thousands of 
billions of VND. Paper manufacturers consume lots of materials produced in the country such as paper materials (wood, bamboo, coal, stone powder, salt ...). This means that paper manufacturers contribute to an increase of productivity, create employment and income for local suppliers of raw materials such as mining, forestry, chemicals and petroleum. This industry also produces outputs for forestry products. Products from the forest such as pine, eucalyptus, acacia, bamboo can be used as raw materials for the paper industry. The development of the paper industry has led to higher interest in afforestation both in terms of quantity and quality. In addition to encouraging the development of forest plantation areas, it is necessary to study the creating of new varieties according to the characteristics of each region.

In 2015, the number of paper manufacturing enterprises in the North was 828 enterprises, however, they were mainly small and medium-sized enterprises. If classified by size of labor, enterprises having 300 employees or less in the North took up $96.74 \%$. Meanwhile, the number of enterprises employing 300 employees or more in the North only accounted for $3.26 \%$.

Table 1: Classification of paper manufacturing enterprises in the North by size of labor

\begin{tabular}{|c|c|c|c|c|c|c|c|}
\hline \multirow[b]{2}{*}{ Year } & \multirow{2}{*}{$\begin{array}{l}\text { Total } \\
\text { number of } \\
\text { enterprises }\end{array}$} & \multicolumn{2}{|c|}{200 employees or less } & \multicolumn{2}{|c|}{ From 200 to 300 employees } & \multicolumn{2}{|c|}{ More than 300 employees } \\
\hline & & $\begin{array}{l}\text { Number of } \\
\text { enterprises }\end{array}$ & $\begin{array}{l}\text { Ratio } \\
(\%)\end{array}$ & $\begin{array}{l}\text { Number of } \\
\text { enterprises }\end{array}$ & Ratio (\%) & $\begin{array}{l}\text { Number of } \\
\text { enterprises }\end{array}$ & $\begin{array}{l}\text { Ratio } \\
(\%)\end{array}$ \\
\hline 2011 & 707 & 662 & 93,64 & 17 & 2,40 & 28 & 3,96 \\
\hline 2012 & 753 & 704 & 93,49 & 21 & 2,79 & 28 & 3,72 \\
\hline 2013 & 744 & 695 & 93,41 & 22 & 2,96 & 27 & 3,63 \\
\hline 2014 & 795 & 748 & 94,09 & 20 & 2,52 & 27 & 3,40 \\
\hline 2015 & 828 & 782 & 94,44 & 19 & 2,29 & 27 & 3,26 \\
\hline
\end{tabular}

If classified by capital size, enterprises with capital of 100 billion VND or less in the North accounted for $88.53 \%$. While enterprises with capital of more than 100 billion VND in the North accounted for only $11.47 \%$.

Table 2: Classification of paper manufacturing enterprises in the North by size of capital

\begin{tabular}{|c|c|c|c|c|c|c|c|}
\hline \multirow[b]{2}{*}{ Year } & \multirow{2}{*}{$\begin{array}{l}\text { Total } \\
\text { number of } \\
\text { enterprises }\end{array}$} & \multicolumn{2}{|c|}{20 billion VND or less } & \multicolumn{2}{|c|}{ From 20 to 100 billion VND } & \multicolumn{2}{|c|}{ More than 100 billion VND } \\
\hline & & $\begin{array}{l}\text { Number of } \\
\text { enterprises }\end{array}$ & $\begin{array}{l}\text { Ratio } \\
(\%)\end{array}$ & $\begin{array}{l}\text { Number of } \\
\text { enterprises }\end{array}$ & Ratio (\%) & $\begin{array}{l}\text { Number of } \\
\text { enterprises }\end{array}$ & Ratio (\%) \\
\hline 2011 & 707 & 487 & 68,88 & 147 & 20,79 & 73 & 10,33 \\
\hline 2012 & 753 & 485 & 64,41 & 194 & 25,76 & 74 & 9,83 \\
\hline 2013 & 744 & 466 & 62,63 & 204 & 27,42 & 74 & 9,95 \\
\hline 2014 & 795 & 517 & 65,03 & 192 & 24,15 & 86 & 10,82 \\
\hline 2015 & 828 & 448 & 54,11 & 285 & 34,42 & 95 & 11.47 \\
\hline
\end{tabular}

(Source: General Statistics Office, research results of real situation of enterprises in 2011, 2012, 2013, 2014, 2015)

Over the last five years, the number of paper manufacturing enterprises has increased steadily, but only with small and medium-sized enterprises. These enterprises have the advantage of being flexible and sensitive to changes in the external environment because of their relatively simple organizational structure. In addition, to save expenses, in these small and medium-sized enterprises, overlapping of responsibility may occur. The checking and controlling activities mainly depend on the management experience of the executives. Due to limited financial capacity, it is difficult for these enterprises to access modern management, inspection and control systems. 


\subsection{Control Environment}

Control environment is a fundamental element in the design and operation of control procedures. Control environment consists of internal and external factors which affect the design and operation of the internal control system. Among surveyed enterprises, $73.33 \%$ reported that their business objective was making profit, only $26.67 \%$ stated that their target was sustainable development. Nowadays, sustainable development has becoming a driving force in all areas of development based on three factors: economic development, social security, and environmental protection. The control environment is influenced by perspectives and business objectives above, but it is also heavily influenced by the capacity and perception of managers about internal control. According to the survey, most managers have not concerned about developing a "risk management culture" in the business (25/30), which may hinder the companies from making timely detection, and developing a culture of risk management ineach individual in the organization.

Currently, enterprises applied line and staff structure, this structure is suitable for relatively largescale enterprises. However, this structure will make management system complicated. Therefore, the leaders must always coordinate operation of many departments to surmount problems such as overlapping of functional departments. The problem of cross checking among departments due to overlapping responsibilities has been reduced (as an administrative manager also manages human resources department); $60 \%$ of enterprises have adjusted the personnel structure when it is not suitable but this adjustment is not conducted frequently.

Furthermore, the staff was unqualified since most of them were unskilled workers with low working standard which made the number of workers unstable. This led to an excess of labor in the indirect sector and a lack of labor in the direct sector. The working environment of workers was affected by heat, dust, noise, etc.

Table 3: Some key factors of working environment in An Hoa Paper Corporation compared with standards of Ministry of Labor, Invalids and Social Affairs (MOLISA)

\begin{tabular}{llll}
\hline No. & Exposing factors & $*$ Standards of MOLISA & Real situations of the enterprise \\
\hline 1 & Heat & $18-30^{\circ} \mathrm{C}$ & $28-33^{\circ} \mathrm{C}$ \\
2 & Dust & $10 \mathrm{mg} / \mathrm{m}^{3}$ & $12 \mathrm{mg} / \mathrm{m}^{3}$ \\
3 & Noise & $90 \mathrm{dBA}$ & $100 \mathrm{dBA}$ \\
4 & Light & $250 \mathrm{Lux}$ & $250 \mathrm{Lux}$ \\
\hline
\end{tabular}

(Source: An Hoa Paper Corporation)

Manufacturing paper is a heavy industry and currently, average income of workers in this sector is 4-7 million VND which is not adequate to their labor. And when workers can find different jobs with easier tasks and lower incomes, they are willing to quit their jobs, especially as indirect workers. For example, in Hong Ha Stationery Joint Stock Company, the number of employees decreased year by year. This is also difficulty for businesses in the future.

Table 4: The fluctuation of number of employees in the company during the period from 2011 to 2015

$$
\begin{array}{llllllll}
\cline { 2 - 7 } & \text { Criteria } & \text { Unit } & \mathbf{2 0 1 1} & \mathbf{2 0 1 2} & \mathbf{2 0 1 3} & \mathbf{2 0 1 4} & \mathbf{2 0 1 5} \\
\cline { 2 - 7 } & \text { Labor } & \text { People } & 578 & 547 & 507 & 458 & 476 \\
\cline { 2 - 6 } \\
\cline { 2 - 6 } \text { (Source: Annual financial reports disclosed by the company during the period from 2011 to 2015) }
\end{array}
$$

According to the survey, most enterprises have set up a supervisory board with 3 members, and their activities partly help to improve business effectiveness. However, the implementation of supervisory board was merely formality due to complaisance. Moreover, segregation of duties is violated when implementingteam and controlling team belong to the same department so the activities of the supervisory board are not performed regularly and partly because manufacturing activities in paper manufacturers are complex, and supervisors are not qualified to optimally meet the requirements of the job. 
According to the interviews, 30 out of 30 respondents stated that the enterprise did not have an internal auditing department, and all control and supervision activities in the enterprise were carried out by the supervisors of the supervisoryboard. $100 \%$ of enterprises supposed that internal auditing in management is not important. This point of view indicates that managers in the enterprises were not aware of and even overlap the tasks and duties of the internal auditing with the board of supervisors, $53.33 \%$ respondents viewed supervisory board and internal auditing are the same. They have not grasped the nature, functions and roles as well as organizing procedures of internal auditing. Thus, the control environment at paper manufacturing enterprises in Northern Vietnam was lacking an important part which is internal auditing. Internal auditing is considered as "an evaluating activity that is set up in the enterprise as a kind of service, with functions of inspecting, evaluating and monitoring the appropriateness and effectiveness of the accounting and internal control system".

\subsection{Risk Assessment}

During the operation of paper manufacturing companies in Northern Vietnam, there exist various risks such as: environmental risks, occupational safety and health; risks of product quality; risks due to the competitive market; financial risks. These risks are always beyond the expectation of the business. The problem with management is that it is impossible to eliminate risk, however, we can take control of and mitigate those risks. Despite of recognizing the importance of risk assessment, in practice, only $56.67 \%$ of surveyed enterprises conducted risk assessment but the risk assessment activities was still passive which did not provide solutions to prevent and reduce risks.

According to self-evaluation of managers of the 17 enterprises conducting the risk assessment, analysis of probability of risks and extent of the impact of risks was mainly based on experience, expert opinions or using a number of analytical methods (SWOT analysis). Specifically, 11 out of 17 enterprises (64.7\%) said that the risk assessment in their enterprises was based on experience; 4/17 (23.5\%) of enterprises relied on experts' opinions to assess risks and $2 / 17$ of enterprises used other methods. According to the survey, the current analysis results were only concluded from qualitative method, not analyzed by quantitative method, so the results were quite general, making it difficult to develop concrete solutions.

In general, managers who carried out risk assessments assumed that this work was important and necessary, but in the implementation process, assessment measures did not bring expected results. 9 out of 17 enterprises (53\%) said that risk assessment measures in their businesses have not been effective; 5 out of 17 enterprises (29.5\%) said that measures to evaluate their business has been effective. According to subjective opinions of managers, this problem may have many causes. This may be due to the manager's level of qualifications, perspectives towards risks and insufficient solutions, passive assessment whichis mainly finding solutions without carefully analyzing the risks to prevent to problems.

During the operation, the target of business is mainly profit. However, risks still exist throughout the course of business operation.According to the principle of balancing risks and benefits, a low level of risk always comes with a low return and, conversely, a higher level of risk is associated with higher returns. According to the survey, 14 out of 30 enterprises (46.67\%) said they were willing to take risks in exchange for maximum of profits; 13 out of 30 businesses (43.33\%) said that profit was the goal but they were not really ready to trade. Accordingly, paper manufacturing enterprises experience certain risks such as: risk of product quality; competitive risk; environmental risk; financial risk and other risks. According to survey results: $12 / 30$ enterprises (40\%) said their biggest risk was product quality; 11 out of $30(36.67 \%)$ of enterprises said that their biggest risk was competition; $3 / 30$ (10\%) said that the environment was the biggest risk; 4 out of 30 businesses $(13,33)$ said their biggest risk was financial risk. Being aware of the risks and accurately assessing the impact of potential risks is an important factor in the effective implementation of IC. But in fact, this factor in the paper manufacturing enterprises in Northern Vietnam still has many shortcomings, so these enterprises need to come up with reasonable solutions in the future.

\subsection{Control Activities}

According to the interview and research results, 63,33\% reported that the enterprise has developed financial management regulations. This financial management regulations of enterprises was based on the organization and labor regulations of enterprises as well as in compliance with the Enterprise Law 
2014. In general, these companies complied with basic control principles such as authorization principle, the principle of non-overlapping magisteria, the principle of responsibility assignment.However, the financial control department has not been developed systematically and effectively. In the organizational structure of the enterprise, there was a lack of two factors, risk control in general and financial risk control in particular which are risk management department and internal auditing department. The analysis of financial indicators from which financial risks can be detected and controlled was conducted by staff of the Finance - Accounting Department instead of independent financial analysts. This result was relevant when $100 \%$ of surveyed enterprises did not have independent financial analysts. The responsibility of making financial decisions lied mainly with the board of directors and the role of the supervisory board has not been fully utilized.

With the development of industries, pollution control has become a challenge and deep concern of our country, including the paper industry. According to survey results, 73,33\% of interviewed enterprises reported that production activities in enterprises have affected the surrounding environment and $26,67 \%$ said that production activities in enterprises have influenced the surrounding environment but infrequently. This is true with the paper industry as pulp and paper producers are required to register procedures of environmental protection because they produce emissions ( like wood dust, cooking odor, chemical odor, boiler, $\mathrm{CO}, \mathrm{CO} 2, \mathrm{SO} 2, \mathrm{NO} 2$, etc.); waste water (such as black liquor, cooling water, separating water, diluting chemicals, condensed water, Ligin, Carbohydrates, suspended solids, other impurities, etc.); Solid waste (for examples ash, wood waste, impurities, discarded separators, oil residues, slag, packaging, scrap). The surveyed enterprises reported that they had implemented and developed various policies to control pollution. However, depending on specific situations, each enterprise implemented established policies at different levels which lead to different results. Among 30 enterprises that answered the questionnaire, only four enterprises have received ISO 14001 certification. The biggest barrier for enterprises to receive certification is high cost of building wastewater treatment system, accounting for $10-15 \%$ of the total costs,moreover, the annual operation cost is not cheap. This cost will increase the price of products, reducing the competitiveness of the business.

It can be said that the application of quality management system ISO 9001 in paper manufacturing enterprises in Northern Vietnam is relatively complete. Specifically, Bac Giang Import-Export Company has strictly implemented the quality management system ISO 9001: 2008 since it was granted with following steps:

- Step 1: Analyzing situations and developing plans

- Step 2: Building quality system

- Step 3: Completing

The ISO team at the company has implemented the changes or additions identified in the assessment of current situations so that the quality system complies with ISO 9001: 2008 standards. The company has developed the Documentation System with 4 levels, details are as follows:

Level 1: Quality book

Level 2: Quality procedures system

Level 3: Instruction documents, forms

Level 4: Quality files

However, due to relatively modest types of paper produced by these enterprises, high quality paper products are limited. Therefore, in the future, it is necessary for enterprises to research and develop good quality paper products, invest in machines, equipment, advanced technology, further strengthening the quality control

\subsection{Information and Communication System}

The accounting function in enterprises has been set up as the accounting and finance department to fully perform the accounting tasks. The assignment of responsibilities was quite clear, and often according to the information provided such as cash accounting, fixed asset accounting, cost accounting, revenue accounting, and so on. According to the survey, $100 \%$ of enterprises provided that the accounting system was assigned with clear responsibilities, ensuringthe consistency. Each section of accounting work was managed by the department head who is in charge of assigning work within the department. 
$86.67 \%$ of respondents have applied the accounting software on computers for accounting tasks, for example, MISA-SME accounting software, ASIA accounting software, ACSOFT accounting software, EFFECT accounting software, etc. They provided that the use of existing software has ensured the accounting work in the enterprises. However, when applying accounting software, some parts still required the combination manual and machine as when calculating salary and payroll using the template designed on Excel. In order to prevent unauthorized access to the accounting software, businesses have developed control procedures such as using password systems and registration of authorization. Only server managed by the head of department will have access to all accounting data, while accountants will only be able to access the tasks they are responsible for. This is also a procedure to limit the potential risk that may arise. According to interview results, only $46.67 \%$ reported that enterprises used management software for the entire unit. Therefore, in the future to compete in the market, enterprises need to study and apply these type of effective management software.

According to the survey, $86.67 \%$ of enterprises think that the transmission of information from the top to lower levels, between departments, members of the unit is relatively reliable. Many internal communication programs were implemented such as: staff meeting for sharing corporate vision, internal news release, internal training materials, motivational speech for staff, information on the intranet, organizing internal playgrounds (sports competitions, vacations, year-end festivals...). The survey results also showed that $53.33 \%$ of enterprises supposed that the feedback from the implementation department to the superiors is not complete. The cause is mainly due to the mindset of the performer who is compliant and hesitant to give his or her opinions.

\subsection{Monitoring Activities}

According to the survey results, 30/30 enterprises conducted monitoring activities in the enterprises. The monitors were internal personnel in the enterprises: supervisory board, senior executives, department managers. However, these monitoring activities in many enterprises did not meet the requirements. There are few enterprises conducting daily monitoring activities, and some enterprises did not carry out periodic monitoring activities. Therefore, only 7 out of 30 enterprises (23.33\%) supposed that their monitoring activities in their units relatively met the requirements. This is also a limitation that paper manufacturers in Northern Vietnam have to overcome in the future. Monitoring activities in paper manufacturing enterprises in Northern Vietnam have not been fully implemented due to lack of consistent policies and procedures. Even though managers concerned about monitoring activities, the implementation process was infrequent and ineffective. In particular, monitoring routines were conducted through feedback from staff and managers in each department. Periodic monitoring activities of many enterprises were not appreciated and usually carried out through review and evaluation of control reports of the supervisory board. Therefore, when there is abnormal fluctuation, it is difficult to detect and control potential risks. Moreover, paper manufacturing enterprises in Northern Vietnam have not organized the internal audit department, which is an effective monitoring tool in the business operations of the company, thus limiting the monitoring results. Moreover, this activity is not conducted on the basis of risk orientation, thus reducing the effectiveness of monitoring and the effectiveness of IC in enterprises.

\section{Conclusion and Recommendation}

According to the analysis above, paper manufacturing enterprises in the North of Vietnam should focus on improving all five factors. Particularly:

\subsection{Control Environment}

Currently, most paper manufacturers in Northern Vietnam have not concerned about building corporate culture, which is also a weakness to overcome in the future. Corporate culture can be understood as the system of values, beliefs, perceptions and thinking methods that all members of the enterprise agree with, which affects each individual's activities. Enterprises should consider building corporate culture as a business mission, an image of the enterprise in the industry and the society, as the direction of the 
long-term development. Every member of the organization must be connected to each other in the spirit of sharing responsibilities, seniors are responsible for guiding the next generation, the manager must act as a model at work and in the daily life. The construction of corporate culture can be proceeded as follows:

- Step 1: Disseminating and communicating to the entire managers and employees about corporate culture.

- Step 2: Design corporate culture

- Step 3: Implementing and building corporate culture

Paper manufacturing enterprises in Northern Vietnam must focus on training human resources in order to improve expertise and skills of employees to help them work more effectively, enhance working skills, improve understanding and ability to think creatively and thus contribute more to their work. In addition, enterprises need to ensure the working environment for workers because in many enterprises, workers in direct production process are affected by factors such as dust, heat, noise which exceed the threshold.

Paper manufacturing enterprises in Northern Vietnam currently have not had an internal audit department, which also reduces the effectiveness of assessment of control activities within the unit. Therefore, enterprises should organize internal auditing as an independent unit that performs regular audits of all activities in the unit, identifies mistakes and weaknesses and take measures to minimize them. Through internal auditing tool, the Board of Directors and managers can be more effective in controlling activities, managing risks, and increasing the ability to achieve business objectives. In order to build the internal auditing, the following steps must be taken: Starting from the development of the regulations and policies of internal auditing; building organizational structure; Developing an audit plan based on risk orientation and training so that internal auditors have sufficient knowledge, skills and qualifications to perform the work.

Nowadays, globalization and international economic integration are happening strongly, widespread and inevitably. At the same time, the explosion of the information technology industry has led to the formation and development of competitive elements, and paper manufacturing enterprises in Northern Vietnam are also affected by that process. there. Paper manufacturers are facing a number of potential risks (such as financial risks, pollution risks, competitive risks, quality risks, etc.) which threaten the viability and development of the business. The majority of paper manufacturers in Northern Vietnam are aiming to create competitive advantages, increase values for businesses and to achieve that goal, enterprises need to build their own strategic plans. And in the implementation of the strategy, there are many risks that affect the process of achieving the goal of the enterprises. Risk management system will be set up to hinder such risks. Therefore, to enhance the effectiveness and alignment of risk management with operation processes, the managers need to make risk management become a factor of corporate culture. Then, it can help to consistently protect, as well as proactively prevent and reduce risks in a systematic and effective way. First of all, employees in the whole enterprise must be educated to be aware of the risks and always have an attitude of managing risks. This activity can be implemented through meetings, workshops, working with consultants, etc. Managers should disseminate risk management at various levels such as functional departments and from there disseminate to every individual in the enterprises. Employees will raise their attitude of managing risk by themselves, for example, in the production process, the habit of turning off unnecessary equipment to prevent the risk of fire and explosion; being careful in the operation of machinery to prevent occupational accidents. In enterprises, it is possible to build comments boxes, hotlines so that when detecting incidents employees can report timely, minimize the risk for businesses. In addition, it is necessary to launch activities with the basic content of motivation, reminding employees to be proactive and aware of risk management for their own benefit and benefit of the enterprise as a whole.

\subsection{Risk Assessment}

In paper manufacturing enterprises in Northern Vietnam, risk assessment activities have been implemented but not synchronized, there are still enterprises that have not conducted this work. Therefore, in the future, paper manufacturing enterprises in Northern Vietnam must implement more control policies, perform the risk management to improve the effectiveness of the assessing activities in 
the enterprises. Paper manufacturers in Northern Vietnam need to improve the risk management process in the following direction

Firstly, developing an appropriate risk management department: The structure of the business should be supplemented with risk management department which will work in conjunction with the internal audit department to exchange results of research, assessment and risk identification within and outside the enterprises. Risk management department will help the board of directors develop standards of risk management system for the entire system to perform specialized tasks. Structure and size of risk management department will depend on the size and level of operations of the business. Functions, duties and powers shall be clearly stated in writing.

Secondly, completing risk management system: The process should include following steps: (1) describing operation of enterprise; (2) identifying risks and weaknesses; (3) quantity analysis of risks; (4) Identifying probability of risks; (5) analyzing and identifying risks; (6) developing solutions

Thirdly, enhancing awareness of members in the enterprise about risk management attitude

\subsection{Monitoring Activities}

It is critical to develop risk management department including staff specializing in financial risk, specialize in each stage of risk management from identification, measurement to forecasting potential risks and measures. If the financial capacity does not allow the establishment of risk management department, the hiring of consultants in the field of financial risk management is also an issue which should be considered by the management. Accordingly, consulting firms will have many advantages in terms of service and experience which help to generate comprehensive solutions to manage risks for enterprises regarding characteristics in the environment of paper industry as well as corporate culture of each business.

Environmental pollution control is one of the top priority tasks for paper manufacturers in the North of Vietnam, especially in those that are not certified ISO 14001. According to the national strategy on environmental protection, $80 \%$ of domestic producers must be certified ISO 14001 by 2020, while the remaining time is not long. On development perspectives, the paper industry in Vietnam has pointed out in the first view that the paper industry in Vietnam must be developed sustainably associated with the task of environmental protection.

Currently, paper manufacturers in the North of Vietnam are mostly applying ISO 9001 quality management system, but this application is not a "ticket" to ensure the quality of products, but only guarantee that these companies have the ability to provide a better, more stable quality requirements of customers. On the other hand, according to research on risk assessment in paper manufacturing enterprises in the North of Vietnam, we find that our paper industry mainly produces medium quality papers and a few categories of paper. Until now, the Government still have not have regulations on quality management criteria specifically for the paper industry. Therefore, in the future, quality control in paper production enterprises in the North of Vietnam should be emphasized by managers. Specifically, to have good quality control, the following solutions should be implemented:

Firstly, continuing to maintain and improve the application of quality management system ISO 9001

Secondly, improving quality management system processes

Thirdly, enhancing the role of people in the quality management system

\subsection{Information and Communication}

Currently, there are still many enterprises that have not yet implemented the application of ERP despite of its great impact on management because of many reasons: cognitive level of management, high investment. However, to increase the effectiveness of control activities in the future those enterprises should apply ERP in accordance with the conditions of the business. The review of ERP application performance needs to be finalized with the following specific measures: (1) application of ERP must be associated with efficiency and accountability; (2) organization of accounting information system should be a top priority when applying ERP; (3) the selection of modules in the ERP system should be tailored to specific characteristics of each enterprise; (4) implementing controlling and evaluating ERP. It is necessary to further enhance the information dissemination among departments of the enterprises, especially the feedback from low levels to managers. 


\subsection{Monitoring Activities}

In paper manufacturers in the North of Vietnam, monitoring and control has been implemented, but the quality of the activities was not good. Therefore, in the near future, monitoring is an important issue that the management and all employees in the enterprises should pay attention to. Monitoring system is the process of monitoring and evaluating the quality of IC to ensure it is deployed, adjusted and continuously improved. Monitoring activities will be good if the companies implement the following solutions: (1) monitoring in three independent control levels: control at departments, risk management department and internal audit. (2) developing a detailed, specific monitoring system: issuing documents and distributing to all staff members in the enterprises such as supervision instructions, monitoring indicators system for self-monitoring, as well as monitoring of the authorities. There is a close association between supervisory board and self-supervision. (3) enhancing capacity for the monitoring system: in particular, continuing training, upgrading qualifications and monitoring capacity of specialized staff. (4) focus on monitoring of risk warning. (5) periodic monitoring should be carried out

\section{Recommendation for Further Research}

This study examined 30 paper manufacturers in Northern Vietnam, so the representativeness and impact of the studty may not be high. Initially, research results have provided some solutions to contribute to improving IC in paper manufacturing enterprises in the North of Vietnam. However, to overcome these limitations, further studies may choose larger sample size, the author should run model to quantify the influence of factors on the effectiveness of IC in paper manufacturing enterprises in the North of Vietnam.

\section{References}

1. A. A. Arens \& J. K. Loebecke, Audit, Thong ke publisher, 2000.

2. A. J. Pfister, "Managing Organzacional Culture for Effective Internal control: From Practice to theory", Physica - Verag, Berlin - Heidelberg, 2009.

3. D. N. Chorafas, "Implementing and auditing the Internal control System". Published by Palgrave Macmillan, 2001.

4. IFAC (2003), "International Standard on Auditing 610", Considering the Word of Internal Audit.

5. L. Giriunas, "Evaluation of Internal Control System in Mining Industry Enterprises in Lithuani", ISSN 1392-1258. EKONOMIKA 2012 Vol.91(2), 2012.

6. N. Q. Quynh. \& N. T. Tue, Financial auditing, National Economic University, 2012.

7. N. P. Giang \& N. T. Le. Internal audit, Tai Chinh publisher, 2014.

8. N. Morelo, "The Importance of Internd Control in the Brazilian Public Administration". School of Business and Public Management. The Institute of brazilian Business \& Public Management Issues Minerva Program, 2011.

9. P. Muraleetharan, "Internal Control and Impack of Financial Performance of the Organizations". (Special Reference Public and Private Organizations in Jaffna District). Universiti of Kelaniya, 2011.

10. Q. Cheng; B. W. Gch \& J. B. Kim, "Internal control and operational efficiency". Association Annual Congress, April 28-30. Reseach Collection School of Accountancy. http://ink.library.smu.edu.sg/Soa- research/1392. 2015

11. R. Bičiulaitis, "Organizacijų vidinė kontrole sistema ir verslo rizikų valdymas. Organizacijų vadyba: sisteminiai tyrimai", Nr. 17. Kaunas: VDU leidykla, p. 17-30, 2001.

12. R. Amanson, "Theoretical and Practical Fishery management", Manciging Fishery resourses Journal, p3-10, 1987.

13. R. R. Moller, "Bringks modern internal auditing" - Sixth Edition, John Wiley \& Sons, InC, 2009.

14. T. T. G. Tan, Internal control, Phuong Dong publisher, 2014.

15. T. P. Dinapoli, "Standards for Internal Control". Access Through the Internet: http://www.osc.state.ny.us/ agencies/ictf/docs/intcontrol-stds.pdf, 2007.

16. The committee of Sponsoring Organizations (1992), "COSO Inteernal Control - Intergrated Framework".

17. The committee of Sponsoring Organizations of the Treadway Commission (2013), "Inteernal Control Intergrated Framework Executive Summary", www.coso.org. 
18. V. Mongkolsamai. \& P. Usshawanitchakit, "Impacts of internal control strategy on efficiency operation of organization of Thailisted firens", International Journol of Business Strategy, Vol 12, No 3: 22-35, 2012. 


\section{Appendix1: List of surveyed enterprises}

\begin{tabular}{|c|c|c|c|c|}
\hline \multirow[b]{2}{*}{ No. } & \multirow[b]{2}{*}{ Name of enterprises } & \multirow[b]{2}{*}{ Address } & \multicolumn{2}{|c|}{ Company size } \\
\hline & & & Capital (VND) & $\begin{array}{l}\text { Number of } \\
\text { employees (people) }\end{array}$ \\
\hline 1 & $\begin{array}{l}\text { PACKEXIM joint-stock } \\
\text { company }\end{array}$ & $\begin{array}{l}\text { Number 49, lane } 15 \text {, An Duong } \\
\text { Vuong street, Hanoi }\end{array}$ & 274.795 .000 .000 & 365 \\
\hline 2 & $\begin{array}{l}\text { Hong Ha stationary joint- } \\
\text { stock company }\end{array}$ & $\begin{array}{l}\text { Number 672,Ngo Gia Tu - Duc } \\
\text { Giang - Long Bien, Hanoi }\end{array}$ & 450.054 .000 .000 & 434 \\
\hline 3 & Diana joint-stock company & $\begin{array}{l}\text { Industrial center Vinh Tuy, } \\
\text { Hanoi }\end{array}$ & 3.506 .441 .000 .000 & 1.137 \\
\hline 4 & $\begin{array}{l}\text { Hai Tien paper joint-stock } \\
\text { company }\end{array}$ & $\begin{array}{l}\text { Industrial center Sai Dong B, } \\
\text { Hanoi }\end{array}$ & 404.955.000.000 & 285 \\
\hline 5 & Tran Thanh ltd. Co & 110, Nguyen Du, Hanoi & 149.724.000.000 & 560 \\
\hline 6 & $\begin{array}{l}\text { Ht Vina joint-stock } \\
\text { company }\end{array}$ & $\begin{array}{l}\text { Industrial center Hapro, Le } \\
\text { Chi, Gia Lam, Hanoi }\end{array}$ & 154.222.000.000 & 228 \\
\hline 7 & Hoa Viet Co., Ltd. & $\begin{array}{l}\text { Residential area Phu Minh, } \\
\text { Hanoi }\end{array}$ & 170.452 .000 .000 & 282 \\
\hline 8 & $\begin{array}{l}\text { Goldsun Packaging \& } \\
\text { Printing JSC }\end{array}$ & $\begin{array}{l}\text { Industrial centerPhu Minh, } \\
\text { Hanoi }\end{array}$ & 428.386 .000 .000 & 459 \\
\hline 9 & Hieu Hien MT Co., Ltd. & Thon Nhue, Hanoi & 201.853.000.000 & 257 \\
\hline 10 & $\begin{array}{l}\text { Van Diem paper joint-stock } \\
\text { company }\end{array}$ & $\begin{array}{l}\text { Phu Minh, Phu Xuyen district, } \\
\text { Hanoi }\end{array}$ & 415.230 .000 .000 & 309 \\
\hline 11 & $\begin{array}{l}\text { Song Da packaging joint- } \\
\text { stock company }\end{array}$ & Do lo, Yen Nghia, Hanoi & 283.256.400.000 & 216 \\
\hline 12 & Nam Hai Co., Ltd & Area A, Tu Liem, Hanoi & 290.126 .400 .000 & 221 \\
\hline 13 & $\begin{array}{l}\text { An Hoa paper joint-stock } \\
\text { company }\end{array}$ & $\begin{array}{l}\text { Vinh Loi, Son Duong district, } \\
\text { Tuyen Quang province }\end{array}$ & 9.099 .905 .000 .000 & 1.157 \\
\hline 14 & $\begin{array}{l}\text { Yen Bai Joint Stock Forest } \\
\text { Agricultural Products And } \\
\text { Foodstuff Company }\end{array}$ & $\begin{array}{l}\text { Nguyen Phuc, Yen Bai } \\
\text { province }\end{array}$ & 104.916.000.000 & 646 \\
\hline 15 & $\begin{array}{l}\text { Hoang Van Phu Paper } \\
\text { joint-stock company }\end{array}$ & $\begin{array}{l}\text { Quan Trieu district, Thai } \\
\text { Nguyen province }\end{array}$ & 334.803.000.000 & 334 \\
\hline 16 & $\begin{array}{l}\text { Vinabiz joint-stock } \\
\text { company }\end{array}$ & $\begin{array}{l}\text { Number } 1, \text { Nguyen Van } \mathrm{Cu} \\
\text { street, Tran phu district, Bac } \\
\text { Giang province }\end{array}$ & 610.756 .000 .000 & 452 \\
\hline 17 & $\begin{array}{l}\text { Viet tri paper joint-stock } \\
\text { company }\end{array}$ & $\begin{array}{l}\text { Song Thao street, Phu Tho } \\
\text { province }\end{array}$ & 708.960 .000 .000 & 665 \\
\hline 18 & Vietnam paper corporation & $\begin{array}{l}\text { Phong Chau town,Phu Ninh } \\
\text { distric, Phu Tho province }\end{array}$ & 2.666.988.000.000 & 1.590 \\
\hline 19 & $\begin{array}{l}\text { Bbp paper joint-stock } \\
\text { company }\end{array}$ & Tam Vong, Phu tho province & 782.562 .000 .000 & 213 \\
\hline 20 & $\begin{array}{l}\text { Phu Giang Papers and } \\
\text { packaging company }\end{array}$ & Tam Tao, Bac Ninh province & 371.943 .000 .000 & 550 \\
\hline 21 & Tan Thanh Dong company & $\begin{array}{l}\text { Industrial center Tan Hong, } \\
\text { Bac Ninh province }\end{array}$ & 229.478.000.000 & 245 \\
\hline 22 & $\begin{array}{l}\text { Hoang Thach packaging } \\
\text { joint-stock company }\end{array}$ & $\begin{array}{l}\text { Minh Tan town, Hai Dương } \\
\text { province }\end{array}$ & 103.202.000.000 & 202 \\
\hline 23 & $\begin{array}{l}\text { Trung Kien joint-stock } \\
\text { company }\end{array}$ & Pho Ga, Hai Duong province & 304.835 .000 .000 & 351 \\
\hline 24 & Ap packing Co., Ltd. & $\begin{array}{l}\text { Number } 6 \text {, industrial center } \\
\text { Nam Sach, Hai Duong province }\end{array}$ & 320.156 .000 .000 & 380 \\
\hline 25 & Hapaco Hai Au Co., Ltd. & $\begin{array}{l}\text { 441A TonDuc Thang, Hai } \\
\text { Phong }\end{array}$ & 290.763.000.000 & 560 \\
\hline
\end{tabular}




\begin{tabular}{|c|c|c|c|c|}
\hline 26 & $\begin{array}{l}\text { Sapa Vietnam joint-stock } \\
\text { company }\end{array}$ & Dinh Du, Hung Yen province & 1.104.914.000.000 & 321 \\
\hline 27 & $\begin{array}{l}\text { Viet Hung packaging Co., } \\
\text { Ltd. }\end{array}$ & $\begin{array}{l}\text { Km } 17 \text {, highway } 5 \text {, Hung yen } \\
\text { province }\end{array}$ & 448.809 .000 .000 & 952 \\
\hline 28 & Toan Phat Co., Ltd. & Ben village, Hung Yen province & 108.938.000.000 & 220 \\
\hline 29 & $\begin{array}{l}\text { Minh Tam Group joint- } \\
\text { stock company }\end{array}$ & $\begin{array}{l}\text { Industrial center Pho Noi B, } \\
\text { Hung Yen province }\end{array}$ & 269.375.000.000 & 272 \\
\hline 30 & $\begin{array}{l}\text { But Soncement } \\
\text { packingjoint-stock company }\end{array}$ & $\begin{array}{l}\text { Km 2, Cao vân street, Nam } \\
\text { Đinh province }\end{array}$ & 212.670.000.000 & 254 \\
\hline
\end{tabular}

\section{Appendix 2: Information about the contribution of the enterprises}

$\begin{array}{lllllll}\text { Year } & \begin{array}{l}\text { Number of } \\ \text { employees }\end{array} & \begin{array}{l}\text { Net } \\ \text { revenue }\end{array} & \begin{array}{l}\text { New revenue per } \\ \text { employee (million } \\ \text { VND) }\end{array} & \begin{array}{l}\text { Budget } \\ \text { submission }\end{array} & \begin{array}{l}\text { Budget } \\ \text { submission to } \\ \text { revenue ratio (\%) }\end{array} & \text { Capital }\end{array}$

\begin{tabular}{lllllll}
\hline 2011 & 43705 & 29877539 & 684 & 1179850,2 & 3,95 & 38110076 \\
2012 & 44281 & 32828109 & 741 & 1225066,6 & 3,73 & 42744270 \\
2013 & 46052 & 36808621 & 799 & 1318971,9 & 3,58 & 45975029 \\
2014 & 44363 & 40678283 & 917 & 1576540,8 & 3,88 & 49458471 \\
2015 & 48309 & 45525792 & 942 & 1800244,8 & 3,95 & 55020749 \\
\multicolumn{2}{l}{ The entire industry } & & & & & 947106825 \\
2011 & 1565078 & 1108222457 & 708 & 60111219 & 5,42 & 1078682824 \\
2012 & 1640310 & 1351309746 & 824 & 60928547 & 4,51 & 1314318401 \\
2013 & 1774660 & 1719423696 & 969 & 73023499 & 4,25 & 1545907624 \\
2014 & 1943934 & 1985411182 & 1021 & 78957920 & 3,98 & 1929993443 \\
2015 & 2151156 & 2473147255 & 1150 & 107562084 & 4,35 & \\
\hline
\end{tabular}

\section{Appendix 3: Questionnaire}

\section{Questionnaire about internal control system}

Dear Managers,

For the purpose of researching, validating the current status of internal controls currently applied in paper manufacturing enterprises in Northern Vietnam to provide comments and recommendations to improve the effectiveness of your management, please take some time to answer the designed questionnaire sent to you in the envelope. The information you provide will be served the research purposes only and will not be provided to anyone without your consent.

Instruction:

- $\quad$ Choose suitable answers and mark directly on the sheet.

- $\quad$ With open-ended questions, please write the answer on the doting lines

- $\quad$ The survey is conducted by sending envelop with stamp attached in this envelop

Part I: General information about respondent and enterprise

(1) Name of respondent:.................department:

(2) Enterprise's name:

Address:

(3) when was your company established?

Pursuant to the establishment Decision No. /.............

(4) What is the type of enterprise?

1. A wholly-own foreign enterprise 


\begin{tabular}{|l|l|}
\hline 2. A limited liability enterprise & $9 / 30$ \\
\hline 3. A joint stock enterprise & $19 / 30$ \\
\hline 4. A Public enterprise & $2 / 30$ \\
\hline 5. A joint venture enterprise & \\
\hline 6. Others & \\
\hline
\end{tabular}

(5) Chartered capital of the company:.

(6) Average number of workers currently:

(7) Average salary of workers currently:

(8) Current products of the company:

(9) importing markets of the company currently:

(10 Exporting markets of the company currently:

(11) Strategic objective of the company from 2015 to 2025

\section{Part II: Evaluation of internal control of enterprise}

\section{A. Control environment}

1. What is the operation objective of the company?

\begin{tabular}{|l|l|}
\hline Maximizing profit & $22 / 30$ \\
\hline Sustainable development & $8 / 30$ \\
\hline Others & \\
\hline
\end{tabular}

2. Does the company develop "risk management culture"?

\begin{tabular}{|l|l|}
\hline Yes & $5 / 30$ \\
\hline No & $25 / 30$ \\
\hline
\end{tabular}

3. What is your company's structure?

\begin{tabular}{|l|l|}
\hline Line structure & \\
\hline Functional structure & \\
\hline Line and functional structure & $30 / 30$ \\
\hline
\end{tabular}

4. Does the management of the company regularly monitor and make adjustments to the organizational structure when it is inappropriate?

\begin{tabular}{|l|l|}
\hline Yes & \\
\hline Sometimes & $18 / 30$ \\
\hline No & $12 / 30$ \\
\hline
\end{tabular}

5. Does your company have internal audit?

\begin{tabular}{|l|l|}
\hline Yes & \\
\hline No & $30 / 30$ \\
\hline
\end{tabular}

6. According to you, are the functions and duties of the supervisory board similar to internal audit?

\begin{tabular}{|l|l|}
\hline Yes & $16 / 30$ \\
\hline No & \\
\hline Not sure & $14 / 30$ \\
\hline
\end{tabular}

\section{B. Risk assessment}

7. How often does your company carry out risk assessment?

\begin{tabular}{|l|l|}
\hline Frequently & $17 / 30$ \\
\hline
\end{tabular}




\begin{tabular}{|l|l|}
\hline Infrequently & $13 / 30$ \\
\hline
\end{tabular}

If the company conduct risk assessment, please move to question (57), (58)

8. What factor is the risk assessment in the company based on?

\begin{tabular}{|l|l|}
\hline Experience & $11 / 17$ \\
\hline Expertise opinion & $4 / 17$ \\
\hline Others & $2 / 17$ \\
\hline
\end{tabular}

9. In your opinion, are risk assessment measures in the company really effective?

\begin{tabular}{|l|l|}
\hline Yes & $5 / 17$ \\
\hline No & $9 / 17$ \\
\hline Not sure & $3 / 17$ \\
\hline
\end{tabular}

10. Are managers willing to take risks in exchange for maximum profits?

\begin{tabular}{|l|l|}
\hline Yes & $14 / 30$ \\
\hline Sometimes & $3 / 30$ \\
\hline No & $13 / 30$ \\
\hline
\end{tabular}

11.In your opinion, what is your company's biggest risk?

\begin{tabular}{|l|l|}
\hline Quality risk & $12 / 30$ \\
\hline Competiveness risk & $11 / 30$ \\
\hline Environment risk & $3 / 30$ \\
\hline Financial risk & $4 / 30$ \\
\hline Others & \\
\hline
\end{tabular}

\section{Control activities}

12.Does your company currently apply financial regulations?

\begin{tabular}{|l|l|}
\hline Yes & $19 / 30$ \\
\hline No & $11 / 30$ \\
\hline
\end{tabular}

13.Is risk analysis conducted by financial analysts?

\begin{tabular}{|l|l|}
\hline Yes & \\
\hline No & $30 / 30$ \\
\hline
\end{tabular}

14. In your opinion, how often do production activities of the company affect the environment?

\begin{tabular}{|l|l|}
\hline Frequently & $22 / 30$ \\
\hline Unfrequently & $8 / 30$ \\
\hline unaffected & \\
\hline
\end{tabular}

15. Is your company certified for ISO 14001?

\begin{tabular}{|l|l|}
\hline Certified & $4 / 30$ \\
\hline Uncertified & $26 / 30$ \\
\hline
\end{tabular}


16. For quality control, does the company employ the ISO 9001 management system?

\begin{tabular}{|l|l|}
\hline Yes & $28 / 30$ \\
\hline No & $2 / 30$ \\
\hline
\end{tabular}

D. Information and communication of accounting system

17.Is the accounting department clearly assigned?

\begin{tabular}{|l|l|}
\hline Yes & $30 / 30$ \\
\hline No & \\
\hline
\end{tabular}

18. Does your company apply any accounting software?

\begin{tabular}{|l|l|}
\hline Yes & $26 / 30$ \\
\hline No & $4 / 30$ \\
\hline
\end{tabular}

19. If yes, what is that accounting software?

Does the company have management software system for the whole unit?

\begin{tabular}{|l|l|}
\hline Yes & $14 / 30$ \\
\hline No & $16 / 30$ \\
\hline
\end{tabular}

20. In your opinion, is transmission of information from the top to lower levels, between departments, members of the unit is relatively reliable?

\begin{tabular}{|l|l|}
\hline Reliable & $26 / 30$ \\
\hline Unreliable & $4 / 30$ \\
\hline
\end{tabular}

21. Is information reported by implementation department to managers complete?

\begin{tabular}{|l|l|}
\hline Complete & $16 / 30$ \\
\hline Incomplete & $14 / 30$ \\
\hline
\end{tabular}

\section{E. Monitoring activities}

22. Does your enterprise implement monitoring activities?

\begin{tabular}{|l|l|}
\hline Yes & $30 / 30$ \\
\hline No & \\
\hline
\end{tabular}

23. In your opinion, do monitoring activities in your enterprise meet requirements?

\begin{tabular}{|l|l|}
\hline yes & $7 / 30$ \\
\hline No & $23 / 30$ \\
\hline
\end{tabular}

